\title{
Improvement of Density, Viscosity and Cold Flow Properties of Palm Oil Biodiesel by Alcohol Addition
}

\author{
Erinc Uludamar*, Vedat Karaman**», Safak Yildizhan***, Hasan Serin*** \\ *Department of Mechanical Engineering, Cukurova University, 01330, Adana, Turkey. \\ **Department of Automotive Engineering, Istanbul Gelisim University, 34315, Istanbul, Turkey. \\ ***Department of Automotive Engineering, Cukurova University, 01330, Adana, Turkey. \\ (euludamar@cu.edu.tr,vkaraman@gelisim.edu.tr, yildizhans@cu.edu.tr,hserin@cu.edu.tr)
}

Corresponding Author; Vedat Karaman, Department of Automotive Engineering, Gelisim University, 34315, Istanbul,
Turkey, Tel: +90 21242270 00, Fax:+90 21242274 01, vkaraman@ gelisim.edu.tr

Received: 29.04.2016 Accepted: 01.06.2016

\begin{abstract}
Alternative fuel researches has gained very importance due to depletion threads of fossil fuels, strictly narrowing emission regulations and high cost of petroleum. Biodiesel one of the most favorite alternative fuels since it is renewable and cleaner energy source. Many vegetable oils and animal fats are used for biodiesel production as raw material. Palm oil is an edible vegetable oil derived from the mesocarp (reddish pulp) of the fruit of the oil palms which is produced widely in some regions and used as raw material for many industrial sectors. Palm oil can be used as feedstock for biodiesel production but it has some drawbacks such as high viscosity and bad cold flow properties. In this study, some fuel properties of biodiesel produced from palm oil and its blends with various alcohols such as isopropyl alcohol, ethanol, and methanol were investigated. The study showed that the inadequate fuel properties of palm oil biodiesel such as viscosity and cold flow properties can be improved with various alcohol addition with the POME-5\% methanol $\left(\mathrm{CH}_{3} \mathrm{OH}\right)$.
\end{abstract}

Keywords: Biodiesel, False Flax Oil, Camelina Sativa, Transesterification, Fuel

\section{Introduction}

The diesel engines are the dominant tool of the field of commercial transportation and agricultural engine usage because of operational simplicity and fuel economy. Diesel engines have lower fuel consumption compared to petrol engines and higher torque production of diesel engines makes more favorable than gasoline engines[1]. Diesel fuel which is the main fuel of compression ignition engines are petroleum based fossil fuels. Depletion of fossil fuels, high cost and environmental concerns are significant problems and many researchers are studying on these particular subjects.

Alternative fuel researches are getting attention by many researchers. The one of the mostly studied alternative fuels are biodiesels which are produced with transesterification reaction of oil fats with alcohol in the presence of a catalyst. Biodiesel fuel can be produced from vegetable oils and animal fats. The main reason of too much interest on biodiesel fuel is the advantage of being a renewable energy source. Furthermore, being a cleaner energy source due to its extra oxygen content in the chemical composition which enhances the combustion and also sulfur-free structure make biodiesel more ecofriendly. Many researchers investigated various feedstocks for biodiesel production particularly waste materials and non-edible vegetable oils or animal fats [2-12]. On the other hand, biodiesel fuel has some drawbacks such as higher oxides of nitrogen (NOx), lower calorific value, and inadequate fuel properties of some feedstocks for direct usage in diesel engines. Especially, some fuel properties such as density, viscosity and cold flow properties which directly affects the performance of engine and fuel injection system are main problems occur with some feedstocks. In literature there are many studies which investigate the various fuel additives to biodiesels for improving the fuel properties [13-17]. 
Palm oil is an edible vegetable oil derived from the mesocarp (reddish pulp) of the fruit of the oil palms, primarily the African oil palm Elaeis guineensis [18] and to a lesser extent from the American oil palm Elaeis oleifera and the maripa palm Attalea maripa. Biodiesel production from palm oil has been investigated by many researchers. The main drawback of palm oil is being in solid phase in the room temperature which causes inadequate cold flow properties. These important drawbacks were investigated by many researchers to improve the fuel properties with some fuel additives [1922].

In this study, biodiesel produced from palm oil were mixed with various alcohols in order to improve density, viscosity and cold flow properties.

\section{Experimental}

The experimental study was conducted in Petroleum Research and Automotive Engineering Laboratories of the Department of Automotive Engineering at Çukurova University. Palm oil was used as raw material for biodiesel production. The samples of palm oil were supplied from a local oil company, Adana, Turkey.

Palm oil is a edible vegetable oil derived from the mesocarp and common cooking ingredient in the tropical belt of Africa, Southeast Asia and parts of Brazil. It is used in the commercial food industry in some regions due to its low cost [23].

Palm oil methyl ester (POME) was produced by using the transesterification method. In this reaction, methyl alcohol and was used as reactant and catalyst in the reaction was sodium hydroxide $(\mathrm{NaOH})$. The chemicals (methanol and sodium hydroxide) which were used during the experiments were purchased from Merck and methanol was purified prior to use. Before transesterification reaction the palm oil which is in the solid phase was heated and liquefied. In order to obtain best production condition, transesterification reaction was carried out in a spherical glass reactor equipped with reflux condenser, stirrer and thermometer. In the reaction, molar ratio of alcohol to oil was 6:1. The reaction were performed with, methanol 20 wt $\%$, sodium hydroxide 0.5 wt \%, temperature $65{ }^{\circ} \mathrm{C}$, time 90 minutes. Methanol and sodium hydroxide were mixed in order to obtain sodium methoxide. Then, sodium methoxide and palm oil were mixed in the reactor. The mixture was heated up to $65^{\circ} \mathrm{C}$ and kept at this temperature for 90 minutes by stirring. After the reaction period, the crude methyl ester was waited at separating funnel for 8 hours. And then, crude glycerin was separated from methyl ester. Finally, the crude methyl ester was washed by warm water until the washed water became clear and dried at $105{ }^{\circ} \mathrm{C}$ for 1 hour. Finally washed and dried methyl ester was passed through a filter. At the end of the transesterification reaction $98 \%$ conversion of oil was obtained.

In the study, 3 different alcohols were blended with palm oil biodiesel in order to improve some important fuel properties. Alcohols used in the experiments were isopropyl alcohol (2-propanol, $\left.\mathrm{C}_{3} \mathrm{H}_{8} \mathrm{O}\right)$, ethanol $\left(\mathrm{C}_{2} \mathrm{H}_{5} \mathrm{OH}\right)$ and methanol $\left(\mathrm{CH}_{3} \mathrm{OH}\right)$. Each alcohol was blended with palm oil $3 \%$ and $5 \%$ by volume of blend. The blends and the name of test samples were given in Table 1. Some fuel properties alcohols used in this study such as purity, density, melting point, dynamic viscosity, molar mass, and water content were given in Table 2. Table 3 shows the instruments used in this study for fuel property measurements.

Table 1. Experimental fuels

\begin{tabular}{|c|c|c|}
\hline Fuel Name & Composition & $\begin{array}{l}\text { Test Fuel } \\
\text { Number }\end{array}$ \\
\hline $\begin{array}{c}\text { Palm oil methyl ester } \\
\text { (POME) }\end{array}$ & $100 \%$ POME & 1 \\
\hline $\begin{array}{c}\text { POME + Isopropyl } \\
\text { Alcohol }\left(\mathrm{C}_{3} \mathrm{H}_{8} \mathrm{O}\right) \\
\end{array}$ & $\begin{array}{c}97 \% \mathrm{POME}+ \\
3 \% \mathrm{C}_{3} \mathrm{H}_{8} \mathrm{O} \\
\end{array}$ & 2 \\
\hline $\begin{array}{c}\text { POME + Isopropyl } \\
\text { Alcohol }\left(\mathrm{C}_{3} \mathrm{H}_{8} \mathrm{O}\right) \\
\end{array}$ & $\begin{array}{c}95 \% \mathrm{POME}+ \\
5 \% \mathrm{C}_{3} \mathrm{H}_{8} \mathrm{O} \\
\end{array}$ & 3 \\
\hline $\begin{array}{l}\text { POME + Ethanol } \\
\left(\mathrm{C}_{2} \mathrm{H}_{5} \mathrm{OH}\right)\end{array}$ & $\begin{array}{c}97 \% \mathrm{POME} \mathrm{+}^{2} \% \mathrm{C}_{2} \mathrm{H}_{5} \mathrm{OH} \\
\end{array}$ & 4 \\
\hline $\begin{array}{l}\text { POME + Ethanol } \\
\left(\mathrm{C}_{2} \mathrm{H}_{5} \mathrm{OH}\right)\end{array}$ & $\begin{array}{c}95 \% \mathrm{POME}+ \\
5 \% \mathrm{C}_{2} \mathrm{H}_{5} \mathrm{OH}\end{array}$ & 5 \\
\hline $\begin{array}{c}\text { POME + Methanol } \\
\left(\mathrm{CH}_{3} \mathrm{OH}\right)\end{array}$ & $\begin{array}{c}97 \% \mathrm{POME}+ \\
3 \% \mathrm{CH}_{3} \mathrm{OH} \\
\end{array}$ & 6 \\
\hline $\begin{array}{c}\text { POME + Methanol } \\
\left(\mathrm{CH}_{3} \mathrm{OH}\right) \\
\end{array}$ & $\begin{array}{c}95 \% \mathrm{POME}+ \\
5 \% \mathrm{CH}_{3} \mathrm{OH} \\
\end{array}$ & 7 \\
\hline
\end{tabular}

Table 2. Fuel properties of alcohols

\begin{tabular}{|l|c|c|c|c|}
\hline $\begin{array}{c}\text { Specificati } \\
\text { on }\end{array}$ & Unit & $\begin{array}{c}\text { Isopropyl } \\
\text { Alcohol } \\
\left(\mathbf{C}_{\mathbf{3}} \mathbf{H}_{\mathbf{8}} \mathbf{O}\right)\end{array}$ & $\begin{array}{c}\text { Ethanol } \\
\left(\mathbf{C}_{\mathbf{2}} \mathbf{H}_{5} \mathbf{O H}\right)\end{array}$ & $\begin{array}{c}\text { Methanol } \\
\left(\mathbf{C H}_{\mathbf{3}} \mathbf{O H}\right)\end{array}$ \\
\hline $\begin{array}{l}\text { Purity } \\
(\mathrm{GC})\end{array}$ & $\%$ & $>=99,5$ & $>=99.0$ & $>=99,8$ \\
\hline $\begin{array}{l}\text { Density } \\
\left(20^{\circ} \mathrm{C}\right)\end{array}$ & $\mathrm{gr} / \mathrm{cm}^{3}$ & $0,785-0,790$ & $0,791-0,793$ & $0,791-0,793$ \\
\hline $\begin{array}{l}\text { Melting } \\
\text { Point }\end{array}$ & ${ }^{\circ} \mathrm{C}$ & -89 & -116 & $-97,6$ \\
\hline $\begin{array}{l}\text { Viscosity } \\
\text { Dynamical } \\
\left(20{ }^{\circ} \mathrm{C}\right)\end{array}$ & $\mathrm{m} . P a . s$ & 2,20 & 1,2 & 0,545 \\
\hline $\begin{array}{l}\text { Molar Mass } \\
\text { Gr/mol }\end{array}$ & 60,1 & 32,04 & 32,04 \\
\hline Water & $(\mathrm{K} . \mathrm{F})$. & $<=0,5$ & $<=0,5$ & $<=0,1$ \\
\hline
\end{tabular}

Table 3. Fuel properties and measurement devices

\begin{tabular}{|c|c|c|}
\hline Property & Device & Accuracy \\
\hline Density & $\begin{array}{c}\text { Kyoto } \\
\text { Electronics DA- } \\
130\end{array}$ & $\pm 0.001 \mathrm{~g} / \mathrm{cm}^{3}$ \\
\hline \multirow{2}{*}{ Viscosity } & $\begin{array}{c}\text { TANAKA } \\
\text { AKV-202 Auto } \\
\text { Kinematic } \\
\text { Viscosity }\end{array}$ & - \\
& $\begin{array}{c}\text { Tanaka MPC- } \\
102 \mathrm{~L} \\
\text { Pour/Cloud } \\
\text { Point }\end{array}$ & $\begin{array}{c}\text { Pour/Cloud } \\
\text { Point Tester }\end{array}$ \\
\hline
\end{tabular}




\section{Results and Discussion}

\subsection{Oil Properties}

In this study, properties of palm oil were measured before oil samples transesterified. Table 4 shows the fuel properties of crude palm oil.

Table 4. Fuel properties of crude palm oil

\begin{tabular}{|c|c|}
\hline Fuel Property & Crude Palm Oil \\
\hline Density $\left(\mathrm{gr} / \mathrm{cm}^{3}\right)$ & 0,912 \\
\hline Viscosity $\left(\mathrm{mm}^{2} / \mathrm{s}\right)$ & 38,62 \\
\hline Pour Point $\left({ }^{\circ} \mathrm{C}\right)$ & 16,8 \\
\hline Cloud Point $\left({ }^{\circ} \mathrm{C}\right)$ & 19 \\
\hline
\end{tabular}

As it is shown in the table, palm oil has high viscosity and improper cold flow properties. Since it can cause fuel injection damage it is not recommended to use directly in the engine. Firstly it should be transesterified and blended with diesel fuel or with other additives.

\subsection{Experimental Fuel Properties}

In this study, POME and its blends with various alcohols were investigated in order to improve some fuel properties of POME. Table 3 shows the fuel measurement results of experimental fuels.

Table 5. Fuel properties of experimental fuels

\begin{tabular}{|c|c|c|c|}
\hline $\begin{array}{c}\text { Fuel } \\
\text { Property }\end{array}$ & 1 & 2 & 3 \\
\hline $\begin{array}{c}\text { Density } \\
\left(\mathrm{gr} / \mathrm{cm}^{3}\right)\end{array}$ & 0,877 & 0,871 & 0,869 \\
\hline $\begin{array}{c}\text { Kinematic } \\
\text { Viscosity } \\
\left(\mathrm{mm}^{2} / \mathrm{s}\right)\end{array}$ & 4,529 & 4,099 & 3,929 \\
\hline $\begin{array}{c}\text { Pour Point } \\
\left({ }^{\circ} \mathrm{C}\right)\end{array}$ & 7 & 6 & 5,6 \\
\hline $\begin{array}{c}\text { Cloud } \\
\text { Point }\left({ }^{\circ} \mathrm{C}\right)\end{array}$ & 13 & 12,4 & 11,8 \\
\hline
\end{tabular}

According to EN 14214 biodiesel standard the standard values for density, kinematic viscosity are 0,860-0,900 $\mathrm{gr} / \mathrm{cm}^{3}$ and $3,5-5,0 \mathrm{~mm}^{2} / \mathrm{s}$, respectively.

The fuel measurement experiments showed that blending the POME with various alcohols resulted with some important improvements. Density, viscosity, pour point, and cloud point values of palm oil were reduced significantly after transesterification reaction.

Density values of alcohols are lower than POME, thus blending POME with alcohols caused a decrement in density values. Viscosity is a measure of resistance to flow of a liquid due to internal friction of one part of a fluid moving over another, affects the atomization of a fuel upon injection into the combustion chamber and thereby, ultimately, the formation of engine deposits. The general rule is; the higher the viscosity, the greater the tendency of the fuel to cause such problem [20]. Viscosity of crude palm oil was $38,62 \mathrm{cST}$ which is too high. After transesterification reaction viscosity value of POME was 4,529 cST which meets the European and ASTM standards. Blending POME with alcohols further decreased the viscosity values. This improvement makes fuel blend more suitable for fuel injection systems and enhances combustion of fuel.

Pour point is the indicator of the lowest temperature which a fluid can flow. The crude palm oil samples were in the phase of solid-liquid mixture phase. Pour point of palm oil samples was $16,8{ }^{\circ} \mathrm{C}$ which is not suitable for direct usage. Pour point of POME was $7{ }^{\circ} \mathrm{C}$ which is better in comparison with crude palm oil but, still this property is not recommended for low temperature regions.. Alcohol additions to POME improved the pour point values and POME-alcohol blends. Increasing alcohol ratio further decreased the pour point values.

Cloud point of a fuel indicates the temperature below which wax in diesel or biowax in biodiesels form a cloudy appearance. Cloud point of a fuel indicates the tendency of a fuel to plug the filters at cold operating conditions. Cloud point of crude palm oil was $19{ }^{\circ} \mathrm{C}$. As it is mentioned with pour point this property is not suitable for direct use. The cloud point of the POME was $13{ }^{\circ} \mathrm{C}$. Even though, being a better value in comparison with crude palm oil, it is a very high temperature and may cause problems in filters. Blending POME with alcohols improved cloud point values. Increasing alcohol ratio in the blend further improved cloud point values. Pour point and cloud point of a fuel determines the fuel characteristics under cold working situations.

Thus in previous years, numerous studies on the use of technologies and different methods to evaluate optimal conditions of biodiesel production technically have been carried out.[2-5] In this study it was found a similar results that obtained in the previous studies.

The alcohol additions to POME improved fuel properties which investigated in this study. Since the blend ratios of alcohols were small ( $3 \%$ and $5 \%$ by volume) the fuel properties of fuels were not tremendously different. Analyses revealed that the most improvement of density, viscosity and cold flow properties were obtained with the POME-5\% methanol $\left(\mathrm{CH}_{3} \mathrm{OH}\right)$.

\section{Conclusions}

- Biodiesel produced from crude palm oil samples via transesterification reaction.

- The study showed that direct usage of palm oil in engines as fuel is not acceptable due to high density and viscosity and inadequate cold flow properties.

- The density and viscosity values were improved significantly after transesterification reaction.

- Analyses revealed that, cold flow properties of palm oil biodiesel are not acceptable for some cold regions since these values are higher compared to standard 
fuels used in market and contingency of causing fuel injection system failures.

- Blending POME with alcohols improved cold flow properties of test fuels. Increasing alcohol ratio in the blend further improved these values.

- According to study, it not recommended to use crude palm oil or palm oil methyl ester directly in the engine. Direct usage may cause fuel injection system failures.

- Palm oil properties were improved by adding alcohol and it make a more utilizable.

\section{References}

[1] Ramadhas A.S., Muraleedharan C. and Jayaraj S., "Performance and Emission Evaluation of a Diesel Engine Fueled with Methyl Esters of Rubber Seed Oil", Renewable Energy, vol. 30, pp. 1789-1800, 2005.

[2] Ozcanli M., Serin H., Aydin K. and Serin S., "Ricinus Communis (Castor Oil) methyl ester as a natural additive for biodiesel fuel", Energy Education Science and Technology Part A: Energy Science and Research vol. 27(2), pp. 331-336, 2011.

[3] Serin H., M. Ozcanli, M.K. Gokce., G. Tuccar. Biodiesel Production From Tea Seed (Camellia Sinensis) Oil and its Blends With Diesel Fuel" International Journal of Green Energy, vol.10:4,pp. 370-377,2013.

[4] Juan C., Acevedoa C., Hernándeza J.A., Valdés C.F. and Kumar S., "Analysis of operating costs for producing biodiesel from palm oil at pilot-scale in Colombia", Bioresource Technology, vol.188, pp.117-123, 2015.

[5] Anwar F., Rashid U., Ashraf M. and Nadeem M., "Okra (Hibiscus esculentus) seed oil for biodiesel production”, Applied Energy, vol.87, pp.779-785, 2010.

[6] Balusamy T. and Marappan R., "Effect of injection time and injection pressure on ci engine fuelled with methyl ester of thevetia peruviana seed oil", International Journal of Green Energy, vol.7, pp.397-409, 2010.

[7] Saribiyik O.Y., Ozcanli M., Serin H., Serin S. and Aydin K., "Biodiesel production from ricinus communis oil and its blends with soybean biodiesel. Strojniški vestnik", Journal of Mechanical Engineering, vol. 56, pp.811-816, 2010.

[8] Altun S.. "Fuel properties of biodiesels produced from different feed stocks", Energy Educ. Sci. Technol. Part A vol.26, pp.165-174, 2011.

[9] Caynak S., Gürü M., Biçer A., Keskin A. and Içingür Y., "Biodiesel production from pomace oil and improvement of its properties with synthetic manganese additive", Fuel vol.88, pp.534-538, 2009.

[10] Canakci M. and Van Gerpen J.H., "Compression of engine performance and emission for petroleum diesel fuel, yellow grease biodiesel, and soybean oil biodiesel", Trans. ASAE, vol.46, pp.937-44, 2003.
[11] Usta N., "Use of tobacco seed oil methyl ester in a turbocharged indirect injection diesel engine", Biomass and Bioenergy, vol.28, pp.77-86, 2005.

[12] Hamamci C., Saydut A., Tonbul Y., Kaya C. and Kafadar A.B., "Biodiesel production via transesterification from safflower (Carthamus tinctorius L.) seed oil", Energy Sources, Part A, vol.33, pp.512-520, 2011.

[13] Jianxin L.L., Zhi W. and Jianhua X., "Combustion and emission characteristics of diesel engine fueled with diesel/biodiesel/pentanol fuel blends", Fuel, vol.15 pp. 211-218, 2015.

[14] Karabektas M. and Hosoz M., "Performance and emission characteristics of a diesel engine using isobutanol-diesel fuel blends", Renewable Energy, vol.34, pp.1554-1559, 2009.

[15] Yilmaz N. and Vigil F.M., "Potential use of a blend of diesel, biodiesel, alcohols and vegetable oil in compression ignition engines", Fuel, vol. 124, pp. 168172,2014

[16] Yasin M.H.M., Yusaf T., Mamat R. and Yusop A.F., "Characterization of a diesel engine operating with a small proportion of methanol as a fuel additive in biodiesel blend”, Applied Energy, vol.114, pp. 865-873, 2014.

[17] Yasin M.H.M., Mamat R., Yusop A.F., Rahim R., Aziz A. and Shah L.A.," Fuel Physical Characteristics of Biodiesel Blend Fuels with Alcohol as Additives, Procedia”, Engineering, vol.53, pp.701-706, 2013.

[18] Reeves J.B. and Weihrauch J.L., "Consumer and Food Economics Institute (1979). Composition of foods: fats and oils", Agriculture Handbook 8-4. Washington, D.C.: U.S. Dept. of Agriculture, Science and Education Administration. p. 4. OCLC 5301713.

[19] Poon, L.Y., Hashim, H., Mat, R., and Mustaffa, A.A.," Flash point prediction of tailor-made green diesel blends containing B5 palm oil biodiesel and alcohol" Fuel, vol.175, pp.287-2932016.

[20] Puneet V., Sharma M.P. and Gaurav D., "Impact of alcohol on biodiesel production and properties", Renewable and Sustainable Energy Reviews, vol.56, pp. 319-333, 2016.

[21] Lv P., Cheng Y., Yang L., Yuan Z., Li. H. and Luo W., "Improving the low temperature flow properties of palm oil biodiesel: Addition of cold flow improver", Fuel Processing Technology, vol.110 pp. 61-64, 2013.

[22] "Palm Oil Continues to Dominate Global Consumption in 2006/07" (PDF) (Press release). United States Department of Agriculture. June 2006. Retrieved 22 September 2009.

[23] Gerpen J.V., Shanks R.P., Clements D. and Knothe G., "Biodiesel Analytic Methods, National Renewable Energy Laboratory”, Colorado, 2004. 